\title{
Morphological and histological characterization of sexual segment of the kidney in Notomabuya frenata (Cope, 1862) and Aspronema dorsivittatum (Cope, 1862) (Squamata, Mabuyidae)
}

\author{
IARA A. NOVELLI ${ }^{1,2}$, PAOLA R. DE OLIVEIRA ${ }^{1,2}$, MARIA CHRISTINA M.N. \\ CASTAÑON ${ }^{3}$, PILAR C. SILVA ${ }^{2,4}$ and BERNADETE M. DE SOUSA ${ }^{1,2}$

\begin{abstract}
${ }^{1}$ Programa de Pós-Graduação em Ciências Biológicas, Comportamento e Biologia Animal, Universidade Federal de Juiz de Fora, Rua José Lourenço Kelmer, s/n, Campus Universitário, São Pedro, 36036-900 Juiz de Fora, MG, Brazil

${ }^{2}$ Laboratório de Herpetologia, Universidade Federal de Juiz de Fora, Rua José Lourenço Kelmer, s/n, Campus Universitário, São Pedro, 36036-900 Juiz de Fora, MG, Brazil

${ }^{3}$ Departamento de Morfologia, Instituto de Ciências Biológicas, Universidade Federal de Juiz de Fora, Rua José Lourenço Kelmer, s/n, Campus Universitário, São Pedro, 36036-900 Juiz de Fora, MG, Brazil

${ }^{4}$ Programa de Pós-Graduação em Biologia Animal, Departamento de Biologia Animal, Instituto de Ciências Biológicas, Universidade Federal Rural do Rio de Janeiro, BR 465, Km 07, 23890-000 Seropédica, RJ, Brazil
\end{abstract}

Manuscript received on October 30, 2017; accepted for publication on January 25, 2018

\begin{abstract}
The kidneys in two viviparous species of Neotropical lizards, Notomabuya frenata and Aspronema dorsivittatum (Mabuyidae), were investigated by light and scanning electron microscopy in order to determine the presence of the sexual segment of the kidney (SSK) and to study its morphology. The individuals used in this study belong to the Herpetological Collection of the Herpetology Laboratory Reptiles of the Federal University of Juiz de Fora (CHUFJF-Reptiles) and they were collected between the years 2008 and 2012 from the Cerrado region in the state of Minas Gerais, Brazil. The SSK was present only in sexually mature males (with sperm in the testes / epididymis), whereas it was absent in sexually immature males. The nephron in both species consists of renal corpuscle, proximal convoluted tubule, distal convoluted tubule, collecting duct and sexual segment of the kidney. The SSK of the analyzed species were coated with a simple columnar epithelium, with high cells, basal nucleus and in the apical portion innumerable secretory granules. This study adds to the knowledge on reproductive biology and structures related to reproductive strategies of both lizard species and viviparous Neotropical lizards.
\end{abstract}

Key words: Accessory organ, reproduction, secretion granules, skinks, urogenital system.

\section{INTRODUCTION}

The sexual segment of the kidney (SSK) was first observed by Gampert (1866) when studying the

Correspondence to: Paola Rosa de Oliveira

E-mail: paolarooliveira91@gmail.com

* Contribution to the centenary of the Brazilian Academy of Sciences. urinary tube of Natrix natrix (Linnaeus, 1758) (= Tropidonotus natrix) (Colubridae). Subsequently, in the same species, Heidenhain (1868) showed the granular nature of the secretion that filled the cytoplasm of the cells that constituted this differentiated portion of the urinary tube. In analyzing the kidneys of Natrix maura (Linnaeus, 
1758) (= Tropidonotus viperinus) (Colubridae) and Vipera aspis (Linnaeus, 1758) (Viperidae), Tribondeau (1902) also noted the presence of an enlarged portion in the urinary tube. The diameter varied among the species studied. However, Regaud and Policard (1903a, b) were the first researchers to correctly interpret this particular feature of the kidneys of Squamata, through finding that this enlarged portion of the urinary tube existed only in the males of some species of snakes. Because these authors suspected that this segment of the kidneys might have a reproductive function, they named it the "sexual segment". In addition to assigning a sexual meaning to the distal portion of the renal tubules, these authors reported that seasonal oscillation could occur in this structure, which they correlated with cyclical variations in the reproductive organs.

The SSK is a feature observed in the kidneys of Squamata and is characterized by enlargement of a portion of the nephron and/or ureter (Regaud and Policard 1903a, b, Sanyal and Prasad 1966, Gabri 1983, Mendes et al. 2009, Rheubert et al. 2014). It is usually not present in females and immature males of Squamata (Kühnel and Krisch 1974, Del Conte and Tamayo 1973, Sever and Hopkins 2005, Rheubert et al. 2014).

The function of the SSK remains unclear (Misra et al. 1965, Reddy and Prasad 1970, Prasad and Reddy 1972). However, it is believed that the SSK is homologous to the seminal vesicles of mammals, since both respond similarly to androgen hormones (Mendes et al. 2009). The SSK is indispensable for copulation and activities such as spermatogenesis and testosterone production, since it has functions associated with production of pheromones and secretions from the ampullae and ductus deferens, separation of urine from semen inside the cloaca, sperm nutrition and semen retention in the female's cloaca, along with providing a buffer at the female genital opening and thus preventing copulation with other males (Sever et al. 2002, Sever and Hopkins
2005, Rheubert et al. 2014). In this way, studying the SSK helps in understanding the reproductive biology and reproductive strategies of reptiles.

Studies on the reproductive biology of species popularly known as "skinks" have revealed peculiar characteristics of their reproduction and life history. They have features similar to the eutherian mammalian placenta, such as a structure with placentrophic viviparity, early breeding, and pregnancy ranging in duration from 8 to 12 months (Vitt and Blackburn 1991, Blackburn and Vitt 1992, Silva and Araújo 2008, Hernandez-Franyutti and Uribe 2012).

Although the biological and ecological aspects of the skinks have been studied for decades in Brazil, the number of studies elucidating the biology and reproductive strategies of these lizards remains small in relation to the level of biodiversity present in this country. Some reproductive aspects of Notomabuya frenata (= Mabuya frenata) (Cope, 1862) and Aspronema dorsivittatum (= Mabuya dorsivittata) (Cope, 1862) have previously been studied (Vitt and Blackburn 1991, Rocha and Vrcibradic 1999), such as the reproductive cycle, litter size, cycle of fatty bodies and minimum size for sexual maturity (Vrcibradic and Rocha 1998, Vrcibradic et al. 2004). However, there are no studies relating to morphological and histological characterization of the urogenital system of these two species.

Given the importance of the sexual segment of the kidney for reproductive and physiological activities of Squamata and the scarcity of studies addressing this structure in Neotropical viviparous species, the present study aimed to characterize the SSK of Notomabuya frenata and Aspronema dorsivittatum, morphologically and histologically.

\section{MATERIALS AND METHODS}

This study included eight individuals of $N$. frenata (five adult males and two young males) and eight 
individuals of $A$. dorsivittatum (five adult males and two young males), belonging to the reptile section of the Herpetological Collection of the Federal University of Juiz de Fora (CHUFJF-Reptiles). The lizards were collected during previous studies in the Cerrado biome (Novelli et al. 2012, Lucas et al. 2016), in the Reserva Biológica do Boqueirão

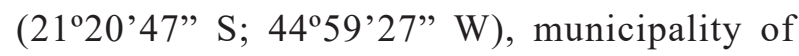
Ingaí, Minas Gerais, Brazil, between September 2008 and January 2012. According to the records at CHUFJF-Reptiles, all of these individuals were fixed in $10 \%$ formalin and stored in $70 \%$ ethanol.

During necropsies on these individuals, part of the urogenital system (kidneys and testes) of each individual was placed in $10 \%$ formalin, to be subjected to histological techniques. Before processing, the tissue sample (Figure 1) was cleaved in cross-section or kept whole for processing. The kidney of two individuals of $N$. frenata (right portion) and two individuals of $A$. dorsivittatum (left portion) were removed for processing according to the technique used for analysis in scanning electron microscopy. For the optical microscopy analysis, the tissue from the urogenital system was dehydrated in increasing concentrations of alcohol
(80\%, 90\% and 100\%), cleared in xylene and embedded in paraffin. Subsequently, histological microtome blocks were cut into serial sections with a thickness of $4 \mu \mathrm{m}$ (Tolosa et al. 2003). The slides were stained with hematoxylin-eosin (H\&E), periodic acid-Schiff (PAS), Alcian blue (AB) at $\mathrm{pH}$ 2.5\% (Rheubert et al. 2011) and Gomori's trichrome. All histological processing was carried out in the Histology Laboratory, Department of Morphology, Institute of Biological Sciences, Federal University of Juiz de Fora (UFJF), Juiz de Fora, Minas Gerais. Analyses on the material and photo documentation were performed using an Olympus BX41 microscope with digital photographic equipment (Canon A3100S) and an ocular micrometer coupled to this microscope.

For the scanning electron microscopy analyses, one kidney from each sexually mature male (two individuals of $N$. frenata and two individuals of A. dorsivittatum) was fixed in $10 \%$ formalin and dehydrated in increasing concentrations of ethanol $(70 \%, 80 \%, 90 \%, 96 \%$ and $100 \%)$. After dehydration, the material was subjected to $97 \%$ 1,1,1,3,3,3-hexamethyldisilazane until dry. The material was mounted on stubs using adhesive tape,
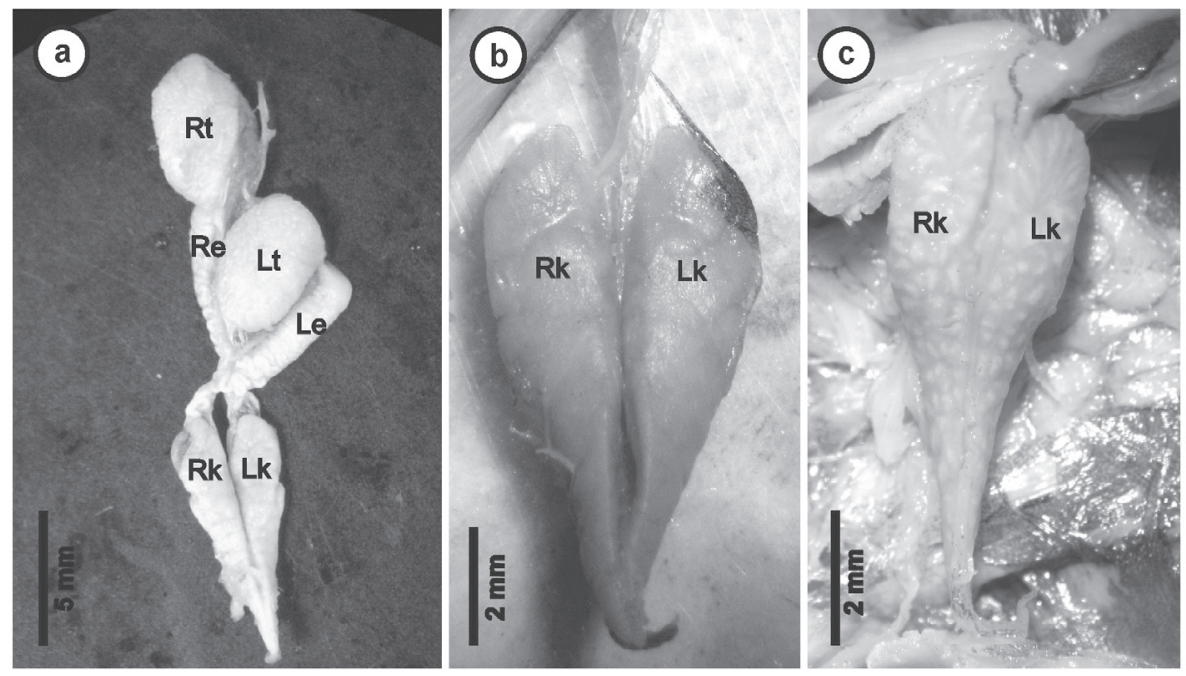

Figure 1 - Urogenital system of Aspronema dorsivittatum (a). Kidney of Notomabuya frenata (b) and of A.dorsivittatum (c). Right testicle (Rt); Left testicle (Lt); Right epididymis (Re); Left epididymis (Le); Right kidney (Rk); Left kidney (Lk). 
metallized with gold, and subsequently analyzed using an FEI Quanta FEG microscope operating at $10 \mathrm{kV}$.

\section{RESULTS}

The kidneys of both species were located in the posterior portion of the trunk, in the studied individuals. Regarding external morphology, the kidneys of $N$. frenata presented a smooth texture whereas in the kidneys of $A$. dorsivittatum, a granular texture was observed (Figure 1b, c).

Through the microscopic analysis of the kidneys of $N$. frenata and $A$. dorsivittatum it was possible to infer that the kidneys organize themselves serially; that is, there is no separation between cortex and medulla (Figure 2).

The renal parenchyma (Figure 2a, c) was characterized by well-defined nephron components (renal corpuscles, proximal and distal convoluted tubules and collecting duct). The renal corpuscles consisted of a glomerulus and corpuscular space (Figure 2). The proximal convoluted tubules (PCTs) were composed of a simple cuboidal epithelium with strong acidophilic cells that were stained more intensely at the edges (or fluted edges or brush border), which was consistent with the presence of microvilli (Figure 2). The distal convoluted tubules (DCTs) were distinguished

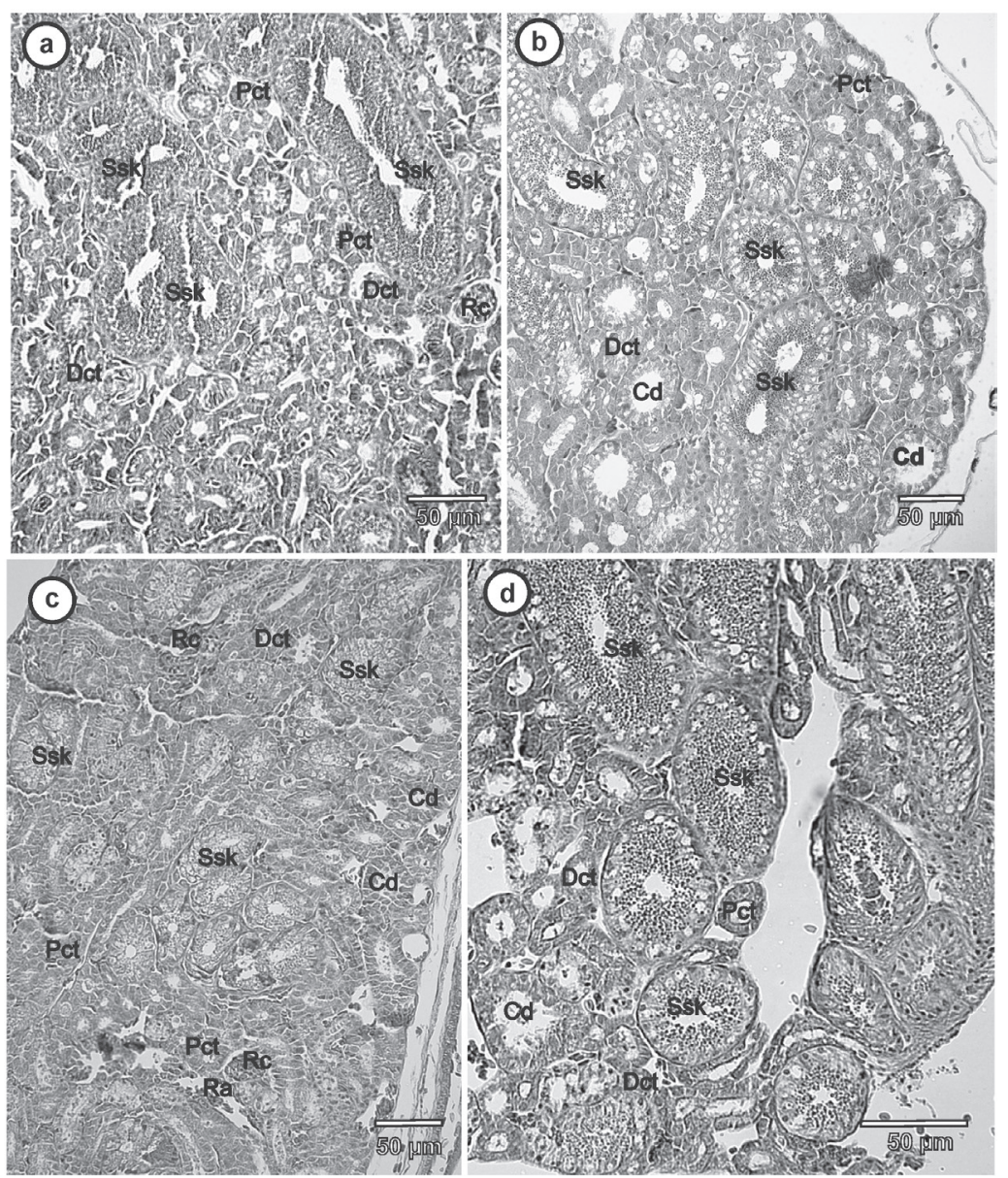

Figure 2 - Light microscopy kidney sections in Notomabuya frenata (a, b) and Aspronema dorsivittatum $(\mathbf{c}, \mathbf{d})$ stained with hematoxylin and eosin (H\&E). Renal corpuscle (Rc); Proximal convoluted tubule (Pct); Distal convoluted tubule (Dct); Collecting duct (Cd); Sexual segment of the kidney (Ssk). 
from the PCTs due to their smaller diameters and simple cuboidal epithelial lining, and were poorly acidophilic (Figure 2). The collecting ducts (CDs) were lined with low columnar epithelia, which indicated secretory activity.

In analyzing the CDs, a modification was observed at the end of this tubule, which took on characteristics differing from those presented previously. Like the cells of the coating epithelium, they became higher, with a nucleus in the basal portion and presence of secretory granules in the apical portion. These were similar to the characteristics presented by the SSK (Figure 2). Thus, through morphological and histological analysis, the SSK of $N$. frenata and $A$. dorsivittatum was characterized as derived from a hypertrophied portion of the collecting tubules.

The SSK was observed in this study only in adult males of $N$. frenata and $A$. dorsivittatum and was not present in the young males analyzed. Using optical microscopy and staining with H\&E, the
SSK was seen to have a coating on the tall columnar cells, with the nucleus in the basal portion of the cell (Figure 2). Lipid vacuoles were observed in the median portion of the SSK of both species (Figure $2 b, d)$.

The scanning electron microscopy (SEM) analysis revealed that the SSK tubule was lined with simple columnar epithelium around a centralized lumen, with presence of secretory granules in the apical portion of the cell (Figure 3).

In the kidneys of the sexually mature males of $N$. frenata (Figure 4a) and A. dorsivittatum (Figure 4b) stained with PAS, the SSK epithelial cells did not present a positive reaction to PAS (Figure $4 a, b$ ). In some regions, a narrow-diameter tubular portion lined with a more flattened, although still columnar epithelium, was observed in the renal parenchyma. The cells of this epithelium presented mild-tomoderate PAS positivity in the apical portion, possibly associated with its secretory composition. In both species studied, transition areas between
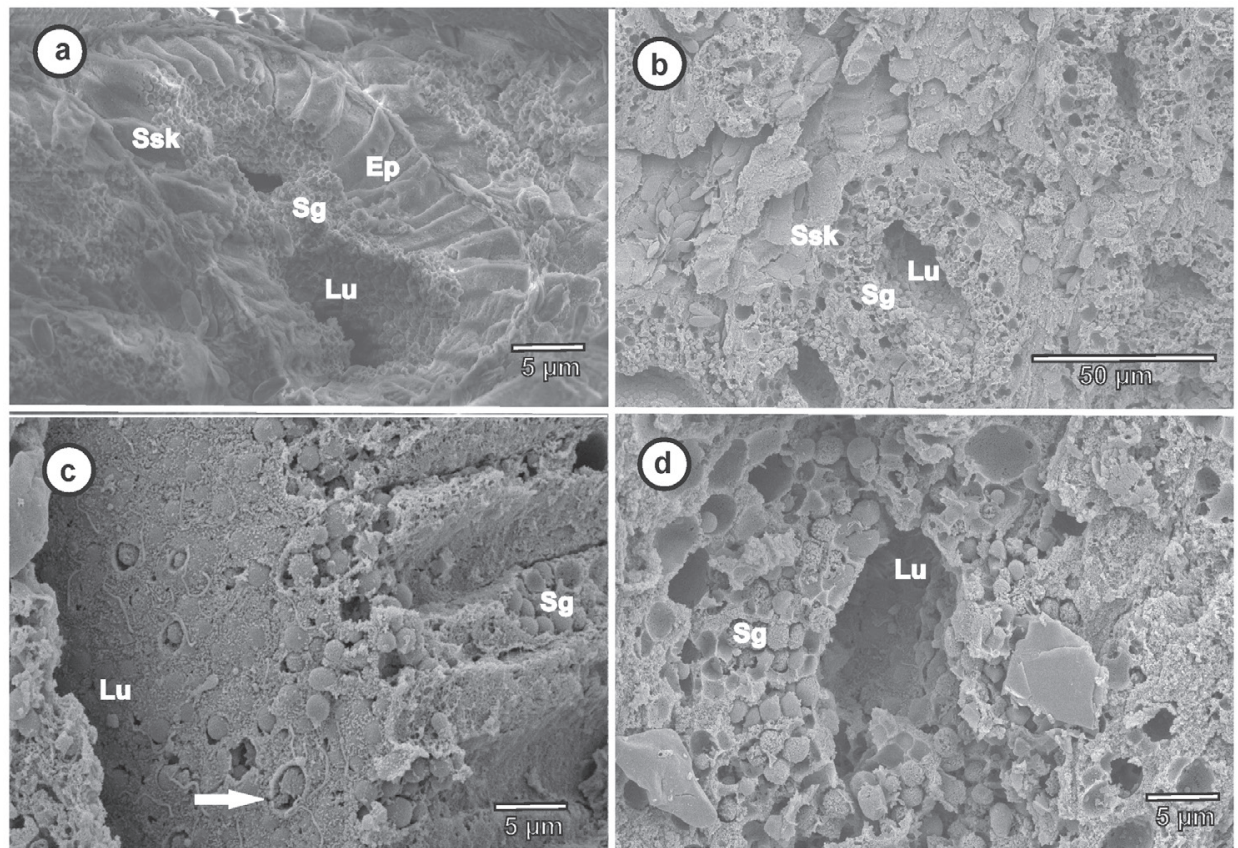

Figure 3 - Scanning electron microscopy kidney sections in Notomabuya frenata (a, c) and Aspronema dorsvittatum (b, d). Sexual segment of the kidney (Ssk); Lumen (Lu); Columnar epithelium (Ep); Secretory granules (Sg); Granules are secreted by epithelial cells (white arrow). 


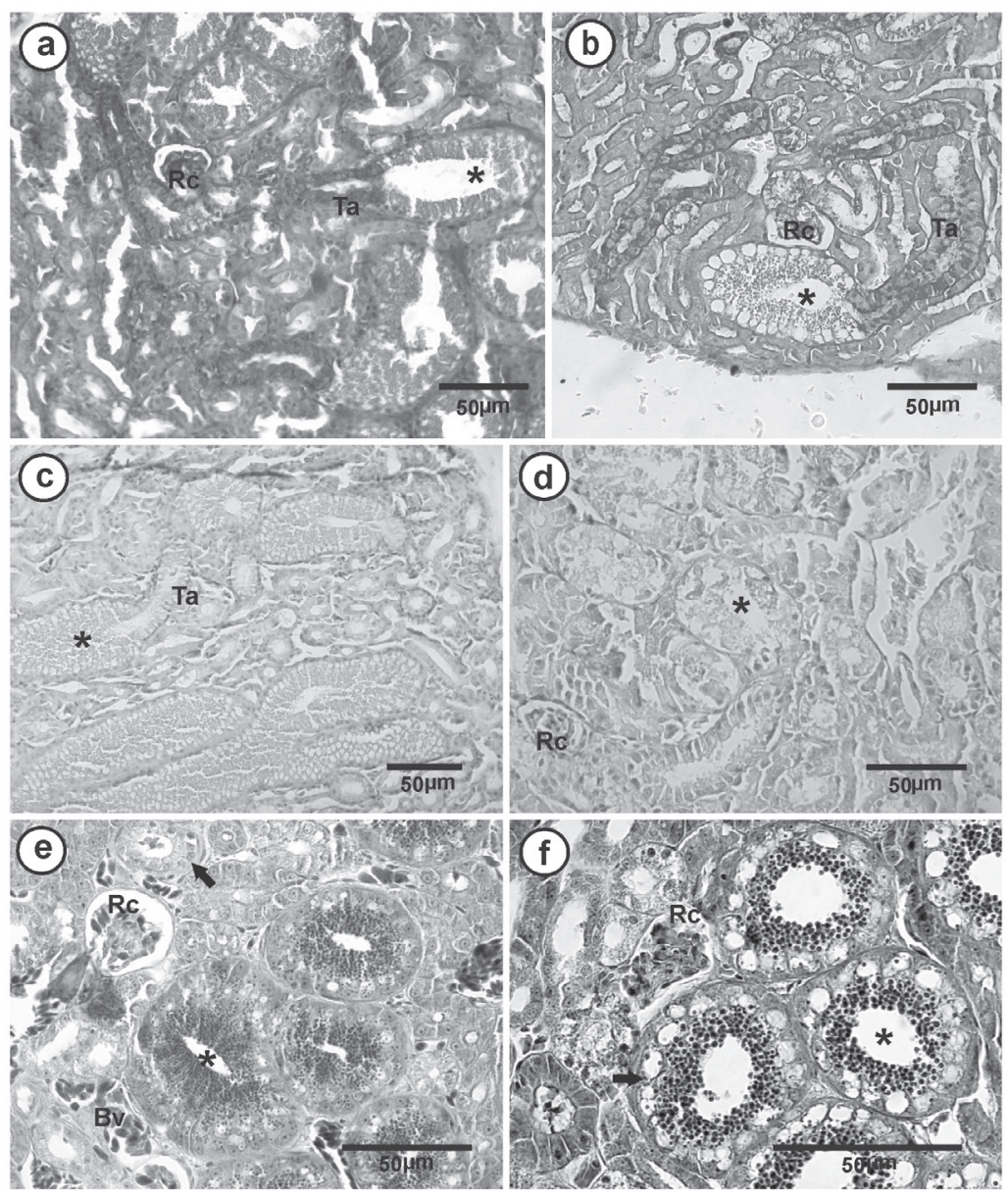

Figure 4 - Light microscopy of kidney sections stained with periodic acid-Schiff (PAS) (a, b), Alcian Blue (AB) (c, d) and Gomori's trichrome (e, f) of Notomabuya frenata (a, c, e) and Aspronema dorsvittatum (b, d, f). Renal corpuscle (Rc); Sexual segment of the kidney $\left(^{*}\right)$; Transition area (Ta); Blood vessel (Bv); Collagen fibers (black arrow).

CD and SSK stained positively with PAS (Figure $4 a, b)$.

Alcian blue staining on the kidneys of $N$. frenata (Figure 4c) and $A$. dorsivittatum (Figure $4 d)$ presented different reactions. The kidneys of $N$. frenata showed mild-to-moderate positivity in the apical portion of some tubules, which characterized the transition area between the CD and the SSK (Figure 4c). The SSK showed a negative reaction to $A B$ in the beads and the vacuoles. Alcian blue staining also showed the transition area between the CD and SSK (Figure 4c). In A. dorsivittatum, there was a negative reaction to $A B$ (Figure $4 d$ ).
Specimens of $N$. frenata (Figure $4 \mathrm{e}$ ) and $A$. dorsivittatum (Figure 4f) showed renal parenchyma with a meager portion of connective tissue in the interstitium (as indicated by Gomori's trichrome), in which there were delicate bundles of collagen around the tubules and the renal parenchyma (Figure 4e, f).

\section{DISCUSSION}

In the individuals of $N$. frenata and A.dorsivittatum analyzed in this study, presence of columnar epithelium of simple columnar type was observed, with tall cells, nucleus in the basal portion and 
secretory granules in the medial and/or apical portion (Table I). These morpho-histological features have been observed in several families of Squamata and are summarized in Table I.

A probable mucoid secretion (as indicated by protein secretory granules) was observed in the SSK lumen of the individuals examined (Figure 2), thus forming a possible muco-proteinic secretion. The form of release of the exocrine secretion in the SSK is variable, and release in holocrine, merocrine and apocrine forms is possible. These forms have also been observed in other studies on the SSK (Table I) (Sanyal and Prasad 1966, Del Conte and Tamayo 1973, Sever and Hopkins 2005, Rheubert et al. 2011, 2014). Sever and Hopkins (2005) pointed out that SSK granules from Scincella lateralis (Say, 1823) (Scincidae) collected in North Carolina (United States) might contain a complex of lipids, glycogen, mucopolysaccharides and phosphatases; and that the chemical composition might change during the reproductive seasons of the year. This emphasizes the need for more detailed studies such as on histochemistry, to elucidate the secretory composition of SSK not only in $N$. frenata and $A$. dorsivittatum, but also in the Squamata group.

The SSK of the individuals analyzed in the present study on $N$. frenata and A. dorsivittatum did not react with PAS and Alcian blue, and was therefore negative for acid and neutral glycosaminoglycans. Mendes et al. (2009) also did not observe any positive PAS reaction in analysis on the SSK of Tropidurus torquatus (Wied, 1820) (Tropiduridae). However, these authors did not analyze the reaction to Alcian blue. Sever et al. (2012) tested the SSK of several snakes from different families and observed both PAS-negative and PAS-positive strains. Sever et al. (2012) observed a positive reaction to Alcian blue only in Homalopsidae. A positive reaction to Alcian blue was also observed in the SSK of Hemidactylus turcicus (Linnaeus, 1758) (Gekkonidae), in an analysis by Rheubert et al. (2011). However, in the majority of the species studied, a negative reaction to Alcian blue was observed, thus indicating that absence of a positive reaction to Alcian blue has, until the present study, been a characteristic of this structure in Squamata. In A. dorsivittatum, neither the SSK nor the Alcian blue-positive transition areas were observed. This can possibly be explained by the difference in secretory composition in relation to the transition area of $N$. frenata. However, more detailed studies, such as on the histochemical components of both SSK and transitional area secretion in both species, would be required.

Del Conte and Tamayo (1973) reported that the first portion of the SSK of Cnemidophorus lemniscatus (Linnaeus, 1758) (Teiidae) had higher affinity for PAS than the second portion. This was because the second portion provides lower glycosaminoglycan secretion content and higher abundance of proteins than the first portion. The absence of positive PAS and Alcian blue findings in the SSK of $N$. frenata and A. dorsivittatum and the presence of positivity in the transition area may be related to the amount or even the presence/ absence of mucopolysaccharides and proteins in the secretory granules of the SSK.

Few studies have investigated the reaction of the SSK to Gömöri's trichrome. The kidneys of $N$. frenata and A. dorsivittatum stained with Gomori's trichrome presented similar reactions around the structures of the renal parenchyma. This result was already expected since the renal tubules are arranged in interstitial tissue containing little connective tissue. Until the present study, the SSK in lizards was characterized as a hypertrophied region of three portions of the nephron (intermediate segment, distal convoluted tubule and collecting tubule) and of the ureter (Rheubert et al. 2014). Rheubert et al. (2011) studied the SSK of Hemidactylus turcicus (Linnaeus, 1758) (Gekkonidae) and presented two phylogenies that took into account the location of the SSK in Squamata, derived from morphological data (provided by Conrad 2008) and molecular data 
TABLE I

Characteristics of the sexual segment of the kidney of Squamata reptiles already studied and those observed in Notomabuya frenata and Aspronema dorsivittatum (present study).

\begin{tabular}{|c|c|c|c|c|c|c|c|c|c|}
\hline Species ${ }^{*}$ & $\begin{array}{c}\text { Study } \\
\text { Country }\end{array}$ & $\begin{array}{c}\text { Reproductive } \\
\text { Mode }\end{array}$ & Epithelium $^{* *}$ & Nucleus $^{* * *}$ & Secretion $^{* * * *}$ & $\begin{array}{l}\text { Hypertrophied } \\
\text { Portion }^{* * * * *}\end{array}$ & PAS & $\mathrm{AB}$ & Reference \\
\hline \multicolumn{10}{|c|}{ LACERTILIA } \\
\hline \multicolumn{10}{|l|}{ Teiidae } \\
\hline $\begin{array}{l}\text { Cnemidophorus } \\
\text { lemniscatus } \\
\text { (Linnaeus, 1758) }\end{array}$ & Venezuela & Oviparous & Columnar & Basal & $\begin{array}{l}\text { Holocrine / } \\
\text { Merocrine }\end{array}$ & $\mathrm{CD}$ & + & - & $\begin{array}{c}\text { Del Conte } \\
\text { and } \\
\text { Tamayo } \\
1973\end{array}$ \\
\hline \multicolumn{10}{|l|}{ Phrynosomatidae } \\
\hline $\begin{array}{c}\text { Phrynosoma } \\
\text { cornutum } \\
\text { (Harlan, 1824) }\end{array}$ & NE & Oviparous & Columnar & Basal & N/A & DCT & $\mathrm{N} / \mathrm{A}$ & N/A & $\begin{array}{c}\text { Anderson } \\
1960\end{array}$ \\
\hline \multicolumn{10}{|l|}{ Lacertidae } \\
\hline $\begin{array}{l}\text { Podarcis tauricus } \\
\text { (Pallas, 1814) }\end{array}$ & $\mathrm{NE}$ & Oviparous & Columnar & Basal & N/A & $\mathrm{DCT} / \mathrm{CD}$ & N/A & $\mathrm{N} / \mathrm{A}$ & $\begin{array}{l}\text { Gabri } \\
1983\end{array}$ \\
\hline \multicolumn{10}{|l|}{ Gekkonidae } \\
\hline $\begin{array}{c}\text { Hemidactylus } \\
\text { turcicus } \\
\text { (Linnaeus, 1758) }\end{array}$ & EUA & Oviparous & Columnar & Basal & Merocrine & $\mathrm{CD}$ & + & + & $\begin{array}{l}\text { Rheubert } \\
\text { et al. } 2011\end{array}$ \\
\hline $\begin{array}{l}\text { Hemidactylus } \\
\text { flaviviridis } \\
\text { Rüppell, } 1835\end{array}$ & India & Oviparous & Columnar & Basal & Apocrine & $\mathrm{CD}$ & + & - & $\begin{array}{c}\text { Sanyal } \\
\text { and } \\
\text { Prasad } \\
1966 \\
\end{array}$ \\
\hline \multicolumn{10}{|l|}{ Tropiduridae } \\
\hline $\begin{array}{c}\text { Tropidurus } \\
\text { torquatus } \\
\text { (Wied, 1820) }\end{array}$ & Brazil & Oviparous & Columnar & Basal & N/A & $\mathrm{CD}$ & - & N/A & $\begin{array}{l}\text { Mendes et } \\
\text { al. } 2009\end{array}$ \\
\hline \multicolumn{10}{|l|}{ Scincidae } \\
\hline $\begin{array}{c}\text { Scincella lateralis } \\
\text { (Say, 1823) } \\
\text { Mabuyidae }\end{array}$ & EUA & Oviparous & Columnar & Basal & Apocrine & $\mathrm{DCT} / \mathrm{CD}$ & + & + & $\begin{array}{c}\text { Sever and } \\
\text { Hopkins } \\
2005\end{array}$ \\
\hline $\begin{array}{l}\text { Notomabuya } \\
\text { frenata } \\
\text { (Cope, 1862) }\end{array}$ & Brazil & Viviparous & Columnar & Basal & N/A & $\mathrm{CD}$ & - & - & $\begin{array}{l}\text { present } \\
\text { study }\end{array}$ \\
\hline $\begin{array}{c}\text { Aspronema } \\
\text { dorsivittatum } \\
\text { (Cope, 1862) }\end{array}$ & Brazil & Viviparous & Columnar & Basal & N/A & $\mathrm{CD}$ & - & - & $\begin{array}{l}\text { present } \\
\text { study }\end{array}$ \\
\hline \multicolumn{10}{|c|}{ SERPENTES } \\
\hline \multicolumn{10}{|l|}{ Viperidae } \\
\hline $\begin{array}{c}\text { Agkistrodon } \\
\text { piscivorus } \\
\text { (Lacépède, 1789) }\end{array}$ & EUA & Viviparous & Columnar & Basal & $\begin{array}{l}\text { Apocrine / } \\
\text { Merocrine }\end{array}$ & PCT & + & + & $\begin{array}{l}\text { Sever et } \\
\text { al. } 2008\end{array}$ \\
\hline Acrochordidae & & & & & & & & & \\
\hline $\begin{array}{c}\text { Acrochordus } \\
\text { granulatus } \\
\text { (Schneider, 1799) }\end{array}$ & Philippines & Viviparous & Columnar & Basal & N/A & DCT & - & - & $\begin{array}{l}\text { Sever et } \\
\text { al. } 2012\end{array}$ \\
\hline \multicolumn{10}{|l|}{ Elapidae } \\
\hline $\begin{array}{c}\text { Micrurus tener } \\
\text { Baird \& Girard, } \\
1853\end{array}$ & EUA & Oviparous & Columnar & Basal & N/A & DCT & + & - & $\begin{array}{l}\text { Sever et } \\
\text { al. } 2012\end{array}$ \\
\hline
\end{tabular}


TABLE I (continuation)

\begin{tabular}{|c|c|c|c|c|c|c|c|c|c|}
\hline Species $^{*}$ & $\begin{array}{c}\text { Study } \\
\text { Country }\end{array}$ & $\begin{array}{l}\text { Reproductive } \\
\text { Mode }\end{array}$ & Epithelium $^{* *}$ & Nucleus $^{* * *}$ & Secretion $^{* * * *}$ & $\begin{array}{l}\text { Hypertrophied } \\
\text { Portion }^{* * * * *}\end{array}$ & PAS & $\mathrm{AB}$ & Reference \\
\hline $\begin{array}{l}\text { Naja samarensis } \\
\text { Peters, } 1861\end{array}$ & Philippines & Oviparous & Columnar & Basal & N/A & DCT & + & - & $\begin{array}{l}\text { Sever et } \\
\text { al. } 2012\end{array}$ \\
\hline $\begin{array}{c}\text { Aipysurus } \\
\text { eydouxii (Gray, } \\
1849)\end{array}$ & Malaysia & Viviparous & Columnar & Basal & N/A & DCT & + & - & $\begin{array}{l}\text { Sever et } \\
\text { al. } 2012\end{array}$ \\
\hline $\begin{array}{l}\text { Ephalophis greyae } \\
\text { Smith, } 1931\end{array}$ & Australia & Viviparous & Columnar & Basal & N/A & DCT & - & - & $\begin{array}{l}\text { Sever et } \\
\text { al. } 2012\end{array}$ \\
\hline $\begin{array}{c}\text { Hydrophis } \\
\text { lamberti Smith, } \\
1917\end{array}$ & Philippines & Viviparous & Columnar & Basal & N/A & DCT & + & - & $\begin{array}{l}\text { Sever et } \\
\text { al. } 2012\end{array}$ \\
\hline $\begin{array}{l}\text { Hydrophis ornatus } \\
\text { (Gray, 1842) }\end{array}$ & Malaysia & Viviparous & Columnar & Basal & N/A & DCT & + & - & $\begin{array}{l}\text { Sever et } \\
\text { al. } 2012\end{array}$ \\
\hline $\begin{array}{c}\text { Hydrophis } \\
\text { platurus } \\
\text { (Linnaeus, 1766) }\end{array}$ & Costa Rica & Viviparous & Columnar & Median & Apocrine & DCT & + & - & $\begin{array}{l}\text { Sever et } \\
\text { al. } 2012\end{array}$ \\
\hline $\begin{array}{c}\text { Laticauda } \\
\text { colubrina } \\
\text { (Schneider, 1799) }\end{array}$ & Philippines & Oviparous & Columnar & Basal & N/A & DCT & + & - & $\begin{array}{l}\text { Sever et } \\
\text { al. } 2012\end{array}$ \\
\hline Homalopsidae & & & & & & & & & \\
\hline $\begin{array}{c}\text { Cerberus } \\
\text { rynchops } \\
\text { (Schneider, 1799) }\end{array}$ & Philippines & Viviparous & Columnar & Basal & N/A & DCT & + & + & $\begin{array}{l}\text { Sever et } \\
\text { al. } 2012\end{array}$ \\
\hline Leptotyphlopidae & & & & & & & & & \\
\hline $\begin{array}{l}\text { Rena dulcis Baird } \\
\text { \& Girard, } 1853\end{array}$ & EUA & Oviparous & Columnar & Basal & N/A & $\mathrm{DCT} / \mathrm{CD}$ & + & - & $\begin{array}{l}\text { Sever et } \\
\text { al. } 2012\end{array}$ \\
\hline Uropeltidae & & & & & & & & & \\
\hline $\begin{array}{c}\text { Teretrurus } \\
\text { sanguineus } \\
\text { (Beddome, 1867) }\end{array}$ & India & Viviparous & Columnar & Basal & N/A & DCT & - & - & $\begin{array}{l}\text { Sever et } \\
\text { al. } 2012\end{array}$ \\
\hline Colubridae & & & & & & & & & \\
\hline $\begin{array}{c}\text { Sibynomorphus } \\
\text { mikanii (Schlegel, } \\
\text { 1837) }\end{array}$ & $\mathrm{N} / \mathrm{E}$ & Oviparous & $\mathrm{N} / \mathrm{E}$ & Basal & N/A & $\mathrm{N} / \mathrm{E}$ & N/A & N/A & $\begin{array}{l}\text { Rojas and } \\
\text { Almeida- } \\
\text { Santos } \\
2008\end{array}$ \\
\hline \multicolumn{10}{|c|}{ AMPHISBAENIA } \\
\hline \multicolumn{10}{|l|}{ Amphisbaenidae } \\
\hline $\begin{array}{c}\text { Amphisbaena } \\
\text { vermicularis } \\
\text { Wagler, } 1824\end{array}$ & Brazil & Oviparous & Columnar & Basal & N/A & $\mathrm{CD}$ & N/A & N/A & $\begin{array}{l}\text { Valverde } \\
\text { et al. } \\
2005\end{array}$ \\
\hline $\begin{array}{l}\text { Amphisbaena alba } \\
\text { Linnaeus, } 1758\end{array}$ & Brazil & Oviparous & Columnar & Basal & N/A & $\mathrm{CD}$ & N/A & N/A & $\begin{array}{l}\text { Valverde } \\
\text { et al. } \\
2005\end{array}$ \\
\hline \multirow[t]{2}{*}{$\begin{array}{c}\text { Amphisbaena } \\
\text { polystergum } \\
\text { (Duméril, 1851) }\end{array}$} & Brazil & Oviparous & Columnar & Basal & N/A & $\mathrm{CD}$ & N/A & N/A & $\begin{array}{l}\text { Valverde } \\
\text { et al. } \\
2005\end{array}$ \\
\hline & & Oviparous & & & & & & & \\
\hline
\end{tabular}

(NA) - not analyzed; (NE) - not specified; (CD) - collecting ducto; (DCT) - distal convoluted tubule; (PCT) - proximal convoluted tubule; (+) - PAS/AB positive; (-) - PAS/AB negative. " Taxonomic classification according to Pyron et al. 2013. ${ }^{* *}$ Epithelium lining the sexual segment of the kidney. ${ }^{* * *}$ Position of the nucleus in the cell lining epithelium of the sexual segment of the kidney. ${ }^{* * * *}$ Figure secretion in epithelial cell lining of the sexual segment of the kidney. ${ }^{* * * *}$ Hypertrophied portion of the kidney. 
(provided by Eckstut et al. 2009). Conrad (2008) presented phylogeny based on morphological data on the head, such as bones and muscles of the skull, while the phylogeny provided by Eckstut et al. (2009) was derived from molecular data relating to the only one nuclear gene (c-mos). According to this study, the SSK of the Scincidae family would comprise hypertrophy of a portion of the collecting tubule and a portion of the ureter, both in morphological and in molecular analysis. Analysis on the two phylogenies revealed that different families shared the location of the SSK according to the characteristics analyzed. This demonstrates how variable the location of SSK is and, furthermore, the need for evolutionary studies relating to this structure in lizards.

Taxonomic studies are mainly based on external morphological characters (such as scales and coloration) and on molecular data (DNA). The difference observed in the external morphology of the kidneys of $N$. frenata (smooth texture) and A. dorsivittatum (granular texture) (Figure 1) indicates a characteristic of the species. In this way, when perceiving the differences in the internal morphology (organs), a complementary form of analysis for taxonomic studies is suggested. Another feature that can be used as taxonomic character is the location of SSK. $N$. frenata and $A$. dorsivittatum previously belonged to the Scincidae family; from the work of Hedges and Conn (2012), were reorganized in the new family Mabuyidae. The hypertrophied region of the nephron for Scincidae was a portion of the collecting tubule and ureter (Rheubert et al. 2011). In the present study, only a hypertrophy of the collecting tubule was observed. This fact differs between the two families; however, it becomes necessary to further study among the species that make up both families to define such a characteristic as a standard.

Several studies on the SSK in lizards (Sanyal and Prasad 1966, Del Conte and Tamayo 1973, Gabri 1983, Sever and Hopkins 2005, Mendes et al. 2009, Rheubert et al. 2011, 2014) have shown a modified sex segment for which cyclical variation would be related to the interstitial cells of the testes. Thus, the activity and hypertrophy of the organ could be an androgen-dependent secondary sexual characteristic (Forbes 1941, Krohmer et al. 2004, Rheubert et al. 2014). However, studies detailing the immunohistochemistry, the consequent function of the secretion from the SSK and the mechanisms involved in its action are needed, both for the lizards in this study and for Squamata generally.

Studies on the SSK in lizards have been conducted more recently than those on this structure in snakes, and in comparison with most studies conducted on oviparous species (Table I). Regarding studies on viviparous species, SSK characterizations are almost nonexistent. Therefore, the present study adds to the knowledge of the reproductive biology and related structures of the reproductive strategies of two species of viviparous Neotropical lizards that hitherto had not been studied. This study has elucidating the morphological and histological characteristics of the SSK, which is a very important structure for understanding the reproductive biology of Squamata (reptiles).

\section{ACKNOWLEDGMENTS}

We thank Larissa Cardoso Barbosa, Caroline Nogueira Aguiar and Matheus Rodrigues Nehrer for assistance in the stages of preparation of histological material. The experiments and analyses involving electron microscopy were performed in the Microscopy Centre of the Universidade Federal de Minas Gerais, Belo Horizonte, Minas Gerais, Brazil. IAN was supported by a Postdoctoral fellowship from Programa Nacional de Pós-Doutorado (PNPD) and Coordenação de Aperfeiçoamento de Pessoal de Nível Superior (CAPES/UFJF) at the Programa de Pós-Gradução em Ciências Biológicas, Comportamento e 
Biologia Animal, UFJF. PRO was supported by a Master Student fellowship from CAPES. PSC was supported by a Doctoral fellowship from CAPES. BMS was supported by Productivity fellowship by Conselho Nacional de Desenvolvimento Científico e Tecnológico (CNPq).

\section{REFERENCES}

ANDERSON E. 1960. The ultramicroscopic structure of a reptilian kidney. J Morphol 106: 205-241.

BLACKBURN DG AND VITT LJ. 1992. Reproduction in viviparous South American lizards of the genus Mabuya. Reproductive biology of South American vertebrates: Springer, p. 150-164.

CONRAD JL. 2008. Phylogeny and systematics of squamata (Reptilia) based on morphology. Bull Am Mus Nat Hist 310: 1-182.

DEL CONTE E AND TAMAYO JG. 1973. Ultrastructure of the sexual segments of the kidney in male and female lizards, Cnemidophorus l. lemniscatus (L.). Z Zellforsch Microsk Anat 144: 325-337.

ECKSTUT ME, SEVER DM, WHITE ME AND CROTHES BI. 2009. Phylogenetic analysis os sperm storage in female squamates. In: Dahnof LT (Ed), Animal Reproduction: New Research Developments. Happauge, New York: Nova Science Publishers Inc., p. 185-218.

FORBES T. 1941. Observations on the urogenital anatomy of the adult male lizard, Sceloporus, and on the action of implanted pellets of testosterone and of estrone. J Morphol 68: 31-69.

GABRI M. 1983. Seasonal changes in the ultrastructure of the kidney collecting tubule in the lizard Podarcis (= Lacerta) taurica. J Morphol 175: 143-151.

GAMPERT O. 1866. Ueber die Niere von Tropidonotus natrix und der Cyprinoiden. Wiss Zoologie 16: 369-373.

HEDGES SB AND CONN CE. 2012. A new skink fauna from Caribbean islands (Squamata, Mabyuidae, Mabyuinae). Zootaxa 3288: 1-244.

HEIDENHAIN R. 1868. Mikroskopische Beitrage zur Anatomie und Physiologie der Nieren. Arch Mikrosk Anat 10: $1-50$.

HERNÁNDEZ-FRANYUTTI A AND URIBE MC. 2012. Seasonal spermatogenic cycle and morphology of germ cells in the viviparous lizard Mabuya brachypoda (Squamata, Scincidae). J Morphol 273: 1199-1213.

KROHMER RW, MARTINEZ D AND MASON RT. 2004. Development of the renal sexual segment in immature snakes: effect of sex steroid hormones. Comp Biochem Physiol A Mol Integr Physiol 139: 55-64.
KÜHNEL W AND KRISCH B. 1974. On the sexual segment of the kidney in the snake (Natrix natrix). Cell Tissue Res 148: 417-429.

LUCAS PS, NOVELLI IA AND SOUSA BM. 2016. Assemblage of squamate reptiles in a natural remnant of Cerrado in southern Minas Gerais, Brazil. Check List 12: 1866.

MENDES RMM, PINHEIRO NL, NASCIMENTO AA, SANTOS CN, RIBEIRO TP, SANTOS MAJ AND SALES A. 2009. Histologia Comparada de Testículo e do Segmento Sexual do rim de Lagarto Tropical Tropidurus torquatus adultos e imaturos. Rev Univ Rural, Sér Ciênc Vida 29: 15-20.

MISRA U, SANYAL M AND PRASAD M. 1965. Phospholipids of the sexual segment of the kidney of the Indian house lizard, Hemidactylus flaviviridis Ruppell. Life Sci 4: 159-166.

NOVELLI IA, LUCAS PS, CARVALHO RG, SANTOS RC AND SOUSA BM. 2012. Lagartos em áreas de Cerrado na Reserva Biológica Unilavras-Boqueirão, Ingaí, Sul de Minas Gerais, Brasil. Biota Neotrop 12: 147-153.

PRASAD M AND REDDY P. 1972. Physiology of the sexual segment of the kidney in reptiles. Gen Comp Endocrinol 3: 649-662.

PYRON RA, BURBRINK FT AND WIENS JJ. 2013. A phylogeny and revised classification of Squamata, including 4161 species of lizards and snakes. BMC Evol Biol 2013: 13-93.

REDDY P AND PRASAD M. 1970. Hormonal control of the maintenance of spermatogenesis and sexual segment in the Indian house lizard Hemidactylus flaviviridis Ruppell. Gen Comp Endocrinol 14: 15-24.

REGAUD C AND POLICARD A. 1903a. Recherches sur la structure du rein de quelques ophidiens. Arch Anat Microsc 6: 191-282.

REGAUD C AND POLICARD A. 1903b. Variations sexuelles de structure dans le segment préterminal du tube urinifère de quelques ophidiens. C R Soc Biol 55: 216-218.

RHEUBERT JL, MURRAY CM, SIEGEL DS, BABIN J AND SEVER DM. 2011. The sexual segment of Hemidactylus turcicus and the evolution of sexual segment location in Squamata. J Morphol 272: 802-813.

RHEUBERT JL, SEVER DM, SIEGEL DS AND TRAUTH SE. 2014. Male reproductive anatomy: the gonadoducts, sexual segment of the kidney and cloaca. In: Rheubert JL, Siegel DS and Trauth SE (Eds), Reproductive biology and phylogeny of lizards and tuatara. CRC Press: Taylor \& Francis Group, p. 253-301.

ROCHA CFD AND VRCIBRADIC V. 1999. Reproductive traits of two sympatric viviparous skinks (Mabuya macrorhyncha and Mabuya agilis) in a Brazilian restinga habitat. Herpetol J 9: 43-53. 
ROJAS CA AND ALMEIDA-SANTOS SM. 2008. Influência do ciclo do segmento sexual renal na determinação do acasalamento em Sibynomorphus mikanii (dormideira) (Serpentes, Dipsadinae). Pesq Vet Bras 28: 154-156.

SANYAL M AND PRASAD M. 1966. Sexual segment of the kidney of the Indian house lizard, Hemidactylus flaviviridis Rüppell. J Morphol 118: 511-527.

SEVER DM AND HOPKINS WA. 2005. Renal sexual segment of the ground skink, Scincella laterale (Reptilia, Squamata, Scincidae). J Morphol 266: 46-59.

SEVER DM, RHEUBERT JL, GAUTREAUX J, HILL TG AND FREEBORN LR. 2012. Observations on the sexual segment of the kidney of snakes with emphasis on ultrastructure in the yellow-bellied sea snake, Pelamis platurus. Anat Rec 295:872-885.

SEVER DM, SIEGEL DS, BAGWILL A, ECKSTUT ME, ALEXANDER L, CAMUS A AND MORGAN C. 2008. Renal sexual segment of the Cottonmouth Snake, Agkistrodon piscivorous (Reptilia, Squamata, Viperidae). J Morphol 269:640-653.

SEVER DM, STEVENS RA, RYAN TJ AND HAMLETT WC. 2002. Ultrastructure of the reproductive system of the black swamp snake (Seminatrix pygaea). III. Sexual segment of the male kidney. J Morphol 252: 238-254.
SILVA VDN AND ARAÚJO AFB. 2008. Ecologia dos lagartos brasileiros. Rio de Janeiro: Technical Books Editora, 271 p.

TOLOSA EMC, RODRIGUES CJ, BEHMER AO AND NETO AGF. 2003. Manual de técnicas para histologia normal e patológica. São Paulo: Editora Manole Ltda., 331 p.

TRIBONDEAU M. 1902. Le tube urinifére des serpents contient trois espéces distinctes d'epithélium sécrétoire. C R Seances Soc Biol Fil 54: 677-679.

VALVERDE MCC, SCHERER PO AND PINHEIRO NL. 2005. Caracterização histológica do segmento sexual do rim de três espécies de Amphisbaenia (Reptilia: Squamata). Sitientibus Ser Ci Biol 5: 3-8.

VITT LJ AND BLACKBURN DG. 1991. Ecology and life history of the viviparous lizard Mabuya bistriata (Scincidae) in the Brazilian Amazon. Copeia 1991: 916-927.

VRCIBRADIC D, CUNHA-BARROS M AND ROCHA CFD. 2004. Ecological observations on Mabuya dorsivittata (Squamata; Scincidae) from a high altitude habitat in South-Eastern Brazil. Herpetol J 14: 109-112.

VRCIBRADIC D AND ROCHA CFD. 1998. Reproductive cycle and life-history traits of the viviparous skink Mabuya frenata in southeastern Brazil. Copeia 1998: 612-619. 